\title{
Munitions and explosives of concern: international governance and applications for the United States
}

\author{
Igor Linkov*, Benjamin D Trump', Renae Ditmer ${ }^{2}$ and Megan Hazle ${ }^{2}$
}

\begin{abstract}
A combination of 20th century warfare alongside the storage of and frequent testing of munitions by various national armed forces has contributed to a legacy of unexploded ordnance, munitions, and explosives of concern (MEC). The presence of such latent munitions has potentially debilitating or even fatal effects upon a generally unsuspecting stakeholders where communities may be unaware of the risks posed by buried shells, bombs, and other ordnance on both public and privately held properties. As such, various governments have undertaken differing initiatives to assess, mitigate, and manage the risks associated with these munitions. MEC remediation is generally tailored to each nation's unique historical experience with munitions and ordnance and is highly dependent not only on the type and quantity of MEC but also on the existing or proposed land use of the parcel as well. This paper compares the MEC management efforts of the United States, the United Kingdom, Germany, and Canada with regard to their MEC monitoring, detection, and removal methods in order to identify successful policies and procedures that can inform international MEC management.
\end{abstract}

\section{Background}

As of 2008, the United States alone was home to an estimated 3,674 sites contaminated with munitions and explosives of concern (MEC) [1]. MEC include specific categories of military munitions such as unexploded ordnance (UXO), discarded military munitions (DMM), and explosive remnants of war (ERW), all hereafter referred to as MEC [2]. Some of these MEC, such as UXO, pose a threat to the general stakeholders' safety as military property is increasingly abandoned following military conflict or when military bases are closed and repurposed for general development and use. In addition, MEC can contain chemicals that are detrimental to humans and the environment, especially if such chemicals leach into waterways or into underground sources of water [3]. Not only are MEC potentially hazardous to human and environmental health, they are often difficult to locate, arduous to manage, and costly to remove. Whether it be MEC remediation of a historical warzone or the clearing of an abandoned or repurposed military facility, MEC remediation is a process that often involves

\footnotetext{
*Correspondence: igor.linkov@usace.army.mil

'US Army Engineer Research and Development Center, 696 Virginia Rd, Concord, MA 01742, USA

Full list of author information is available at the end of the article
}

hundreds of square miles, dozens of personnel, thousands (if not millions) of dollars, and many years to achieve.

The difficulties of determining site risk and in defining 'clean' for MEC sites makes choosing an appropriate future use for each site a risk-infused process [4]. While nations such as the United States, the United Kingdom, Canada, and Germany have concertedly sought to reduce the human and environmental health risks posed by MEC to their respective stakeholders, no single risk analysis or management framework has been developed to govern global MEC risk management. However, each nation in this study has developed strategies and processes that may together be helpful toward achieving that objective in the near future.

Due to the risks associated with MEC identification and removal, MEC removal and subsequent land management fall under the responsibility of multiple government agencies in concert with private companies. As stated, these remediation activities are arduous and expensive. Moreover, current regulation of the MEC removal process is deficient in large part due to ill-defined policy standards for 'clean' for a site from which MEC has been removed. Historically, standards defining 'clean' have been developed on a case-by-case basis given an analysis of the MEC risk present at a particular site and in conjunction with local or national land use regulations, 
stakeholder input, or the Restoration Advisory Boards [5]. Figure 1 demonstrates one such example of how MEC are distributed across large sections in California. Such MEC are extremely difficult to pinpoint and could pose a risk to the local stakeholders if MEC-riddled land is redeveloped or opened for other use.

Because of the spate of challenges faced by many nations in removing MEC, an examination and comparison of how key nations define and achieve international standards 'clean' with regard to MEC-ridden land is required. This study selectively reviews MEC management policy in the United States, the United Kingdom, Canada, and Germany vis à vis current or proposed land use issues in order to evaluate policy, standards, and procedures employed and upon which international standards and procedures might be based. This analysis will hopefully provide MEC stakeholders a more rigorous basis from which to determine whether there is a superior method to assess and manage the potential dangers of MEC given the current and future potential land uses. Particular attention is placed on examining how these nations manage, or fail to manage, risk, along with their definitions of 'clean' as it pertains to their MEC risk assessment and removal processes. From this analysis, all can develop a clearer and perhaps more common understanding of reasonable risk given various land uses where MEC exists and can inform how best to move forward as a global community in solving this worldwide challenge.

\section{Existing efforts for MEC risk discussion}

Prior to this article, the discussion of MEC risk and policy had centered on a specific application of MEC underseas or on land, or given an individual MEC site in a particular country with ongoing or very recent conflict, such as landmines in Cambodia, Afghanistan, and Bosnia [7-9]. For the former, the discussion of MEC and UXO has focused upon human and environmental health and risk assessment, where the costs and consequences of ongoing MEC casualties, pollution, and removal are considered in a general, non-region-specific context [10]. Additional discussions focus on the communication of MEC risks to the local public and their inclusion to developing solutions given proposed land uses of MEC-contaminated sites [11]. For the latter, MEC detection and removal policy alongside the consideration of human and environmental life or health risk is generally considered on a single-country basis in nations that are currently facing military conflict (Afghanistan) or have recently emerged from military conflict in recent years (Serbia) $[8,12]$. Some work also considers the recurring impact of MEC in Western countries from World War I and World War II, although these tend to primarily focus on the divergent policies and risk management efforts of single countries [13,14].

In this article, we utilize the comparative method to assess the similarities and differences in MEC policies, and specifically land use policies, as well as detection, removal, and risk management methods across the aforementioned four Western nations. Where previous efforts to understand MEC risk management have focused on MEC in a particular geographic terrain or on specific MEC policies and risk management schemes in a particular state generally outside of the Western world, we discuss the overall strategies and methods employed by the United States, the United Kingdom,

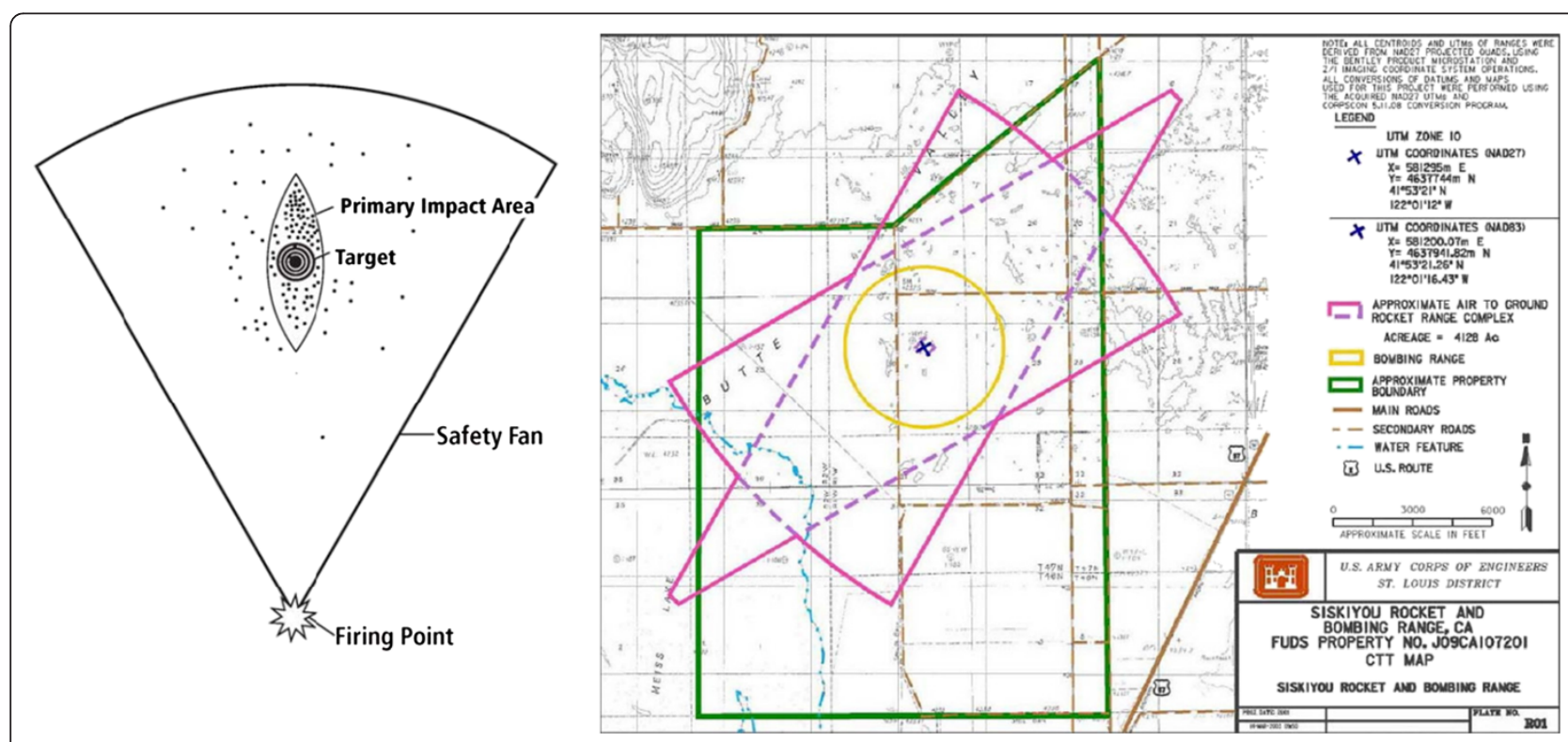

Figure 1 The distribution of MEC given a specific firing point and target (right image). The image on the right shows how these MEC distributions overlap in the Siskiyou Rocket and Bombing Range, CA [6]. 
Germany, and Canada in order to extract and compare the different ways that MEC risk is gauged, mitigated, and managed within each nation. Unique to this comparative paper is the focus on nations with no significant home-based ground war since World War II, and hence where the MEC policy of each nation is currently dealing largely with legacy ordnance and explosive from two world wars including various bases for military drills and live fire exercises. As such, it builds upon the MEC management efforts outlined in historical literature and compares the policies and procedures of these Western nations simultaneously in order to identify those measures which have had more success than others.

\section{Methods}

To establish baseline MEC risk management practices, the United States Department of Defense (DOD) selected four states for comparison: the United States, the United Kingdom, Germany, and Canada. Analysts contracted by DOD then used an established open all source research methodology to answer the questions below and establish comparative research methodology to identify similarities, differences, and outcomes given the risk management criteria across the four countries.

- Definition of MEC

- Primary MEC problem (e.g., MEC, UXO, DMM, ERW, CBRN, etc.)

- Key agencies tasked with MEC management

- Roles of key agencies in MEC management

- Responsibilities of key agencies in MEC management

- Agencies with legal jurisdiction over disposition of land use of MEC sites

- Key policies and guidelines that apply to MEC management, by agency

- Standards that define 'clean', by agency

- Method used to determine risk from MEC

- Landmark legal cases on MEC

- Methods for prioritizing MEC sites for clean up

- Methods and criteria for achieving or assuring 'clean', by agency

- Methods, technology, and procedures employed to achieve, maintain, or monitor 'clean', by agency

- Description of stakeholder involvement in any of the above

- Methodology for updating MEC standards, policies, and procedures

The results were summarized by nation then compared to state-of-the art risk analysis and risk management methodology to determine a way ahead for the United States Department of Defense.

\section{Results}

Using these methods, a comprehensive understanding of international MEC risk management procedures was developed and is outlined in Table 1.

\section{Overview of MEC in Europe and North America}

Internationally, and unbeknownst to the general public, MEC removal has posed a major problem. Both World War II and the cold war spurred technological development that created munitions that could deliver CBRN and which were themselves propelled by poisonous chemicals. Munitions production and usage was rife during WW II, leaving many countries littered with munitions to this day $[15,16]$. Because of this, many countries now face challenges finding and removing MEC in order to return the land to productivity. While most MEC stems from the use of weapons during war, some stems from weapons testing or storage on military sites. As these sites are redeveloped, project managers are forced to deal with public safety concerns in order to realize projects. The United States, the United Kingdom, Germany, and Canada all suffer similar problems and were selected to establish a baseline compendium of knowledge of international MEC management policy, guidance, and practice for each country, and to conduct a comprehensive, comparative review of such to make recommendations for US MEC management policy and practice with regard to current and future potential land uses. Below each country's MEC management strategy is presented, starting with the United States.

\section{The United States}

In the United States, the main MEC of concern are UXOs from both Base Realignment and Closure (BRAC) installations, active installations, and Formerly Used Defense Sites (FUDS) (for purposes of this paper, we focus on BRAC and FUDS installations). Unlike Germany and England, MEC in the United States primarily come from the testing of weapons and are generally not remnants of WWII or the cold war active combat. Because of this, almost all of the MEC-contaminated land is already owned by the DOD. For this reason, the DOD is responsible for remediation actions and cannot lease or transfer by deed any property until it has demonstrated that the property is suitable for its intended use. However, it is not uncommon for MEC contamination to be realized only after future land uses have been identified (and possibly enacted) for the land in question.

To determine future use on BRAC sites, local use or redevelopment authorities (generally referred to as LRAs, though varying in name by community) are established by the local government - generally counties or cities - who have the responsibility for approving land use and addressing use-related issues. LRAs also include business interests and/or citizens, and constitute recommending bodies to 
Table 1 Cross-Country Tabulation of Munitions Remediation and Governance

\begin{tabular}{|c|c|c|c|c|c|c|}
\hline & Who is in charge of regulation? & $\begin{array}{l}\text { Who is responsible for } \\
\text { initiating remediation? }\end{array}$ & $\begin{array}{l}\text { Guidelines to } \\
\text { remediation? }\end{array}$ & How is risk addressed? & How is 'clean' defined? & $\begin{array}{l}\text { Distribution } \\
\text { of MEC? }\end{array}$ \\
\hline $\begin{array}{l}\text { United } \\
\text { States }\end{array}$ & $\begin{array}{l}\text { EPA through CERCLA and imminent and } \\
\text { substantial endangerment provisions of the } \\
\text { safe drinking water act and the military } \\
\text { munitions rule }\end{array}$ & $\begin{array}{l}\text { Local property owner (most } \\
\text { properties are owned by the } \\
\text { DOD, although EPA assists } \\
\text { with oversight) }\end{array}$ & LRAs & $\begin{array}{l}\text { Risk is discussed through MEC } \\
\text { HA, qualitatively discussed }\end{array}$ & $\begin{array}{l}\text { No standard definition, } \\
\text { determined on a case-by-case } \\
\text { basis }\end{array}$ & $\begin{array}{l}\text { Former military } \\
\text { testing facilities }\end{array}$ \\
\hline $\begin{array}{l}\text { United } \\
\text { Kingdom }\end{array}$ & $\begin{array}{l}\text { Local authorities unless designated as a } \\
\text { special site (under EA's jurisdiction) or is } \\
\text { owned by the MOD (under MOD's } \\
\text { jurisdiction) }\end{array}$ & Property owners & $\begin{array}{l}\text { Private industry: } \\
\text { CIRIA MOD: LQAs } \\
\text { and LQS }\end{array}$ & $\begin{array}{l}\text { No standard definition, } \\
\text { qualitatively discussed }\end{array}$ & $\begin{array}{l}\text { No standard definition, } \\
\text { determined on a case-by-case } \\
\text { basis }\end{array}$ & $\begin{array}{l}\text { Throughout } \\
\text { the country }\end{array}$ \\
\hline Germany & Determined by the state & $\begin{array}{l}\text { Property owners (most } \\
\text { properties are owned by } \\
\text { the government) }\end{array}$ & None & $\begin{array}{l}\text { There is national discussion of } \\
\text { risk, and models have been } \\
\text { developed and qualitatively } \\
\text { discussed }\end{array}$ & $\begin{array}{l}\text { No standard definition. } \\
\text { Determined on a case-by-case } \\
\text { basis }\end{array}$ & $\begin{array}{l}\text { Abandoned } \\
\text { military sites }\end{array}$ \\
\hline Canada & $\begin{array}{l}\text { Federal Government (CCME and the } \\
\text { Canadian Environmental Assessment } \\
\text { Act) and provinces }\end{array}$ & $\begin{array}{l}\text { Property owners (most } \\
\text { properties are owned by } \\
\text { the government) }\end{array}$ & $\begin{array}{l}\text { National } \\
\text { Contaminated Sites } \\
\text { Remediation Program, } \\
\text { DND, and DCC }\end{array}$ & $\begin{array}{l}\text { Risk assessments are } \\
\text { performed and qualitatively } \\
\text { discussed }\end{array}$ & $\begin{array}{l}\text { 'Clean' defined by XRRSC or the } \\
\text { CCME, no site can be fully 'clean', } \\
\text { determined on a case-by-case basis }\end{array}$ & $\begin{array}{l}\text { Former military } \\
\text { testing facilities } \\
\text { and offshore sites }\end{array}$ \\
\hline
\end{tabular}


the local decision-making authorities which are usually city councils or county commissions. A land use plan approves the zoning of the property, the specific use of the land parcel, and any requirements for 'clean' that the US government must meet before the land is put into use. The formulation of a land use plan takes into account a number of factors including environmental, economic, and cultural conditions as well as historic considerations, habitat issues for endangered or threatened species [17]. In order to sell or lease the land for the approved use, the DOD is generally required to perform various risk assessments and site characterizations to determine the appropriate remediation or response actions for the intended future land use [18], depending on the type and level of contamination. In actual practice, however, jurisdictional authority to approve the disposition of land for a particular use may be complicated by outside factors such as congressional intervention to resolve disputes over future land uses, local politics, and local stakeholders political action groups. Throughout this process, the DOD typically consults state, local, and tribal regulatory authorities as well as federal land managers such as the Bureau of Land Management, Forest Service, and the Fish and Wildlife Service [19] and adjacent stakeholders and business on the proposed land use and how to use the land safely. Public opinion can drive the decision at the local level, and its involvement is generally required by the local authorities, and the local planning commission usually requires DOD to garner and address public comments from public comment periods [20] or hold public hearings. This makes the entire approval process ultimately rather subjective since public opinion can sway approval to a significant degree.

MEC removal standards outlined in the Comprehensive Environmental Response, Compensation and Liability Act (CERCLA) govern the site recovery process. Authority to implement CERCLA is granted to the President of the United States, and Executive Order 12580 (23 Jan 1987) tasks the Environmental Protection Agency (EPA) as the primary oversight body in any MEC response action. The DOD likewise holds response authority at certain nonNational Priority List (NPL) [21] sites for non-emergency remedial and removal actions. Under CERCLA and EO 12580, the responsible federal agency land holder is designated via CERCLA as the 'lead agency' for carrying out the response action, with the EPA maintaining an oversight role. Section 120 also requires that an interagency agreement be signed between the EPA and lead response agency for a National Priority List (NPL) site to ensure the expeditious clean-up of the site. Furthermore, The Community Environmental Response Facilitation Act (CERFA) amended CERCLA to require that the EPA concur with uncontaminated property determinations made by the DOD at NPL sites.
Along with CERCLA, the Military Munitions Rule established by the EPA to identify when military munitions become hazardous wastes regulated under RCRA subtitle $C$ also plays a role in United States MEC removal. Through the Military Munitions Rule, the EPA asserts that munitions used for their intended purposes at active ranges are not regulated as a solid or hazardous waste. However, activities including recovery, collection, as well as disposal actions consistent with range clearance were determined not to be within the scope of the intended purpose for the munitions, and therefore categorized as solid and/or potentially hazardous waste. Though exemptions to the RCRA do exist for emergency response to MEC hazards, remedial actions are subject to EPA oversight. In some cases, however, the EPA has delegated implementation authority to states exercising similar or more stringent standards.

In 2008, EPA, in conjunction with the DOD, the Department of the Interior, the Association of State and Tribal Solid Waste Management Officials, and the Tribal Association for Solid Waste and Emergency Response, led the most recent attempt to provide a standardized MEC risk assessment and management framework. Building upon a number of previously developed methodologies for risk assessment and site prioritization, the EPA's MEC Hazard Assessment (MEC HA) provides a means to qualitatively address human health and safety concerns at a MECcontaminated site. According to EPA, this interim methodology will assist site managers and regulators in evaluating explosive safety hazards to people at munitions response sites consistent with the Comprehensive Environmental Response, Compensation, and Liability Act [22]. This approach uses a subjective scoring methodology that assesses a site's risk level on a scale between 125 and 1,000 points. This score in turn results in a corresponding risk level assessment on a ranked scale from 1 to 4 based upon inputs for nine site attributes. In contrast to risk assessments conducted under CERCLA, MEC HA does not address environmental or ecological concerns. Also, although MEC HA can be used at several points in the CERCLA process, it is primarily intended for use at the end of either a removal or remedial investigation in order to assess baseline explosive hazards and relative hazard reductions associated with the removal or remedial alternatives in the engineering evaluation/cost analysis (EE/CA) or remedial investigation/feasibility study (RI/FS). The MEC HA may therefore be utilized to establish a baseline for comparison of removal and remediation alternatives.

While MEC HA is a positive step towards needed risk characterization, it does have some shortcomings. In such a system, stakeholders - and sometimes the DOD itself do not know nor can they determine the actual number of MEC items that might remain on a site post clean-up. This makes determining an appropriate future site use difficult 
and likely influences approval of a proposed land use negatively. Given the uniqueness of each site, a site's future use must be determined on a case-by-case basis. Also, MEC HA does not have the ability to measure the probability of harm occurring from a MEC explosion or give a quantitative estimate of the resulting level of damage, rendering objective risk assessment methodology nearly useless. Finally, MEC HA does not account for future remediation costs [23]. These shortcomings have caused alternative risk characterization methods to be explored. Furthermore, the United States Office of the Secretary of Defense Acquisition, Technology \& Logistics (DUSD (I\&E)/EM) does not believe that the current methodology is adequate for evaluating baseline explosive hazards given current or anticipated land use. Because of these shortcomings in risk assessment and because of an increasingly global community, this study looks internationally at other countries' procedures in an attempt to determine how the US can move forward in MEC removal and management.

\section{The United Kingdom}

MEC within the United Kingdom (UK) is common due to airstrikes and subsequent weapons use dating from WWII. This has contributed to policies that hold property owners rather than the military responsible and liable for MEC damage on their property. Local authorities are responsible for regulating the safety of these property owners, and they often work in conjunction with property owners to make sites MEC-free. However, there are exceptions to these rules. Some sites are designated as 'special sites', and fall under the Environment Agency's (EA's) jurisdiction. A site is designated as a 'special site' for a variety of reasons, including when it

1. Has been the site of refining of crude oil, petroleum, shale, or other bituminous substance other than coal or the manufacture of explosives

2. Has been used as a nuclear site

3. Has been owned or occupied by or on behalf of the military, military organization, or foreign military force

4. Has been the site of the manufacture, production, or disposal of chemical or biological weapons

5. Is adjacent to a site with the above characteristics [24]

The other regulatory distinction is for property owned by the Ministry of Defense (MOD). In this case, not only is the MOD liable if MEC on their property detonates or leaks but also for ensuring that any land sold or leased is not contaminated or a danger to the public. However, this regulation does not ensure that $100 \%$ of all MEC contaminants have been removed from these sites. According to regulation, the MOD will not be held responsible for losses that may occur because of reliance on such documentation. Overall, the United Kingdom's MEC risk management system places more responsibility and liability in the hands of civilian property owners.

Given this regulatory strategy, the United Kingdom does not provide much MEC risk management guidance, and there are no official quantitative MOD standards to provide risk-based analysis as to whether a MEC site is safe and MEC-free. On the non-governmental side, there is also no official valid and reliable standardized method which defines MEC risk. Recognizing this gap, the Construction Industry Research and Information Association (CIRIA) has published a UXO guidebook to assist private land owners, developers, and construction industry personnel in understanding the nature of the MEC problem, what their legal responsibilities are, and what to expect when dealing with companies offering UXO desk studies or remediation services [25]. In this guide book, CIRIA suggests a two-step approach: first, a qualitative preliminary risk assessment and then, if necessary, a more detailed risk assessment. However, the final output of the more detailed study can be characterized as a qualitative product and one which relies largely on the subjective judgment of the analysts. Some companies that perform this MEC risk assessment try to provide quantitative analyses based on intrusive geo-physical surveys and other site specific calculations, which enables baseline assessments and calculations of estimated residual risk. But these quantitative assessments are not required nor, again, are they methodical, valid, or reliable.

Although the MOD does not have detailed MEC risk management guidance, it does have a regulated approach to quantify risks resulting from land contamination [26]. The MOD utilizes Land Quality Assessments (LQAs) which include both non-intrusive and intrusive investigations of a site and consists of five phases:

1. Phase 0: Preliminary risked-based strategic assessment and prioritization

2. Phase I: Desk study/site walkover

3. Phase II: Intrusive site investigation

4. Phase III: Option appraisal

5. Phase IV: Management response

These result in LQS which provide a non-technical statement regarding the land quality of the site [27]. The assessment broadly characterizes risk of injury from surface, sub-surface, and deep-buried MEC contamination, as well as chemical contamination. Mitigation measures and residual risk are also broadly considered and a risk rating is calculated by multiplying likelihood (as assessed on a four-point scale from most unlikely to most likely) by the potential severity of injury or harm (similarly assessed on a four-point scale from trivial injury/harm to major injury/harm or death). The resulting risk rating (based upon 
the product of likelihood and severity) is one of four 'rating bands' from minimal risk to high risk, with associated, minimally defined suggested control actions [27].

While UK MEC risk is addressed by both private property owners and the MOD, the methods used are oftentimes qualitative. No method exists that iteratively and effectively qualifies risk in a context-rich situation, which makes it difficult to determine appropriate future land use. Also, the UK's current practices make it difficult to define 'clean' concretely or to expand that definition either throughout the United Kingdom or internationally.

\section{Germany}

For Germany, MEC itself is distributed somewhat differently than it is in the United Kingdom. Most MEC in Germany is centered on the many sites that hosted military troops not only during both world wars but also throughout the cold war. Due to Germany's strategic position during the cold war until 1990, over 3,700 square miles of 137,846 total square miles German property - or almost 3\% of all land - were used for military purposes. In the former West Germany, this included sites used by the German Federal Armed Forces as well as those used by the Western Allies (United States, United Kingdom, France, Canada, Belgium, and the Netherlands). In the former East Germany, this included sites used by the National People's Army of the German Democratic Republic (GDR) as well as sites used by the former Soviet Armed Forces. When foreign troops were withdrawn from Germany following the political revolution of 1989, the GDR's National People's Army was dissolved and the size of the German Federal Armed Forces was reduced, which resulted in a significantly reduced need for the large number of military sites in Germany [28]. The total area of abandoned military sites in Germany is now approximately 1,900 square miles, all of which must undergo investigation and potential remediation before they can be used for civilian purposes. All of these abandoned military sites since 1991 have been transferred to the general property of the German government, making the German government responsible for the majority of the MEC contamination. The military's ownership of most of the MEC-contaminated property is similar to the distribution of MEC-contaminated property in the United States. However, as the German government sells this land back to the German people for redevelopment, the new owners become responsible and liable for contamination on site.

In general, there are three different categories of military sites owned by the Federal Government:

1. Sites used by German armed forces throughout history (includes Federal Armed Forces
(Bundeswehr) and the National People's Army of East Germany (NVA))

2. Sites used by troops stationed in Germany under bilateral treaties or NATO

3. Sites used by the allies after World War II (Western Allies and Armed Forces of the former Soviet Union based in East Germany (WGT))

Responsibility for each of these categories falls to different branches within the government as outlined in Table 2. Military sites are considered potentially contaminated until proven otherwise, and once a site is proven to pose a risk to the environment and/or humans, it is subject to the environmental laws and standards of the German state in which it is located. Despite the scope of the problem, there are no national regulations for site cleanup [28]. However, some laws were enacted to empower general oversight committees in an effort to coordinate remediation efforts. There are national laws governing contaminated sites in general. A committee of environmental ministers and a joint working group was formed to harmonize waste, water, and soil legislation between German states, and some of these laws do cover MEC removal. However, they only cover MEC removal on civilian sites not on militaryowned sites [29].

Nationally, there have also been several risk assessment models used over the years to evaluate suspected military contamination sites (such as BEMA, MEMURA, MAGMA, or KOSAL). These models generate a benchmark figure that can then be used to prioritize the sites according to the risk they pose to humans and the environment. Despite the quantitative nature of such assessments, in reality, the prioritization of contaminated sites is strongly influenced by other factors such as regional planning, privatization issues, authority requests, and political decisions. A model (PRISAL) has been developed to account for the socio-economic and political factors that affect the prioritization of contaminated sites, but it has yet to be used in management [28].

Additionally, while risk management is a generally recognized science in Germany, there is no national definition of 'clean'. Typically, contaminated sites are dealt with on a case-by-case basis and remediated appropriately according to intended future use. However, unlike the United Kingdom, most of this remediation is done by the German military instead of civilians. In this respect, Germany's MEC removal process is more similar to the United States. A primary difference between Germany and the US is the notion that all MECcontaminated sites are subject to the management, requirements, and laws of the local and environmental authorities of the relevant state [28]. 
Table 2 Federal responsibility for current and former military sites in Germany

\begin{tabular}{|c|c|c|c|c|c|c|c|}
\hline & & \multicolumn{3}{|l|}{ Current military sites } & \multicolumn{3}{|l|}{ Former military sites } \\
\hline & & $\begin{array}{l}\text { Federal Ministry } \\
\text { of Defense (BMVg) }\end{array}$ & $\begin{array}{l}\text { Treasury } \\
\text { (BMF) }\end{array}$ & $\begin{array}{l}\text { Federal Ministry for Urban and } \\
\text { Regional Planning and Construction } \\
\text { (BMBau) }\end{array}$ & $\begin{array}{l}\text { Federal Ministry of } \\
\text { Defense (BMVg) }\end{array}$ & $\begin{array}{l}\text { Treasury } \\
\text { (BMF) }\end{array}$ & $\begin{array}{l}\text { Federal Ministry for Urban and Regional } \\
\text { Planning and Construction (BMBau) }\end{array}$ \\
\hline \multirow[t]{3}{*}{$\begin{array}{l}\text { Sites used by German } \\
\text { Forces }\end{array}$} & $\begin{array}{l}\text { Federal Armed Forces } \\
\text { (Bundeswehr) }\end{array}$ & Manage $^{\dagger}$ & & & Manage* & & Risk minimization and remediation \\
\hline & $\begin{array}{l}\text { National People's Army } \\
\text { of East Germany (NVA) }\end{array}$ & N/A & N/A & N/A & & Manage & Risk minimization and remediation \\
\hline & $\begin{array}{l}\text { Former German forces } \\
\text { (prior to 1945) }\end{array}$ & N/A & N/A & $\mathrm{N} / \mathrm{A}$ & & Manage & Risk minimization and remediation \\
\hline \multirow{2}{*}{$\begin{array}{l}\text { Sites used by troops } \\
\text { stationed in Germany }\end{array}$} & Bilateral treaties & & Manage & & Manage $^{*}$ & & \\
\hline & NATO & Manage $^{\dagger}$ & & & Manage $^{*}$ & & \\
\hline \multirow{2}{*}{$\begin{array}{l}\text { Sites used by the Allies } \\
\text { WW II }\end{array}$} & Western Allies & & Manage & & & Manage & Risk minimization and remediation \\
\hline & $\begin{array}{l}\text { Armed Forces of the } \\
\text { Soviet Union (WGT) }\end{array}$ & N/A & N/A & N/A & & Manage & Risk minimization and remediation \\
\hline
\end{tabular}

for Environment, Nature Conservation and Nuclear Safety Department (BMU); N/A, not applicable. 


\section{Canada}

Within North America, like the United States, Canada is also plagued with MEC. UXOs are the primary MEC contaminant in Canada and are the result of operational activities and weapons testing as well as the prior use of land areas and lakes as military munitions training areas [30]. This is quite similar to the situation in the United States, where MEC is also almost exclusively the result of weapons testing. Additionally and little known to the general public, wartime activity during WW II along Canada's coasts has resulted in heavy MEC contamination. Moreover, as a result of population growth in Canada, land previously used as training ranges which has since been abandoned has become increasingly developed for civilian use, resulting in a need to effectively address MEC sites. Approximately 1,100 off-shore MECcontaminated sites [31] and an estimated 2,500 on-shore sites have been identified in Canada [32]. Since the constitution act grants the federal government the power to legislate regarding the land use on property which it owns or has an interest in, most environmental matters involve a complex set of negotiations between the federal and provincial governments. In turn, the courts of justice determine which level of government has the power to pass laws regarding environmental issues [33].

Regardless of which government entity has jurisdiction over the MEC-contaminated land, the remediation guidelines are the same. In 1989, the National Contaminated Sites Remediation Program was launched to address human health and environmental quality concerns regarding contaminated sites in Canada [34]. This regulation was followed in 2005 by the creation of the Department of National Defense (DND) Unexploded Explosive Ordinance and UXO Legacy Sites Program to address the challenge of MEC management [35]. This program states that sites can never be cleared $100 \%$, and that there is no criterion that allows a site to be ruled 'safe.' The program has similarly asserted that based upon Canadian experiences, MEC have produced limited environmental impacts, resulting in the characterization of MEC as a public safety issue rather than a contamination issue [35]. Also within the DND, the Defense Construction Canada (DCC) is responsible for contracting and overseeing MEC removal. The DCC provides additional environmental guidelines.

Risk is evaluated across Canada's regulatory process, although only qualitatively. The DND UXO and Legacy Sites Program conduct risk assessments at each identified MEC-contaminated site. These risk assessment programs assess the probability of human (receptor) interaction with a MEC item and the probability that the receptor's interaction will result in the MEC item detonating. Two types of risk assessment are conducted by the Legacy Sites Program:
1. A programmatic prioritization which qualitatively designates a site as high, medium, or low risk prioritization for risk mitigation action.

2. A site-specific risk assessment which addresses acceptable residual risk and clearance methodology in order to achieve a risk level consistent with a previously established future land use [36].

It is recognized in Canada that a more quantitative approach to risk management would improve MEC risk management. In 2008, this need was addressed through a case study of a project undertaken by the DND UXO and Legacy Sites Program at Lac Saint-Pierre, Quebec. This study indicated the advancement of a semiquantitative approach to risk management at the site level used in conjunction with a Geographic Information System (GIS) [35]. Building upon the national prioritization of sites through the assessment of human interaction and explosion probability, the site-specific assessment model additionally considers environmental attributes. The result is a 'global risk index' or (GR) which provides a relative risk index for evaluating a site.

Canada is also aware of the need for a definition of 'clean'. For DND MEC-contaminated sites, the determination of 'clean' is made by the Explosive Risk Rating Sub-Committee (XRRSC) on a site-by-site basis. The XRRSC is a sub-committee of the UXO Sites Working Group (UXOS WG) chaired by the UXO Program whose members include experts in UXO, munitions, and EOD. The XRRSC determines the overall risk by integrating human interaction factors - to include explosive ordnance exposure pathways and the intended use of the site - and explosive risk probabilities so that appropriate measures to reduce the risk commensurate with the end-use plan for a site can be undertaken [36]. For non-DND sites, the Canadian Council of Ministers of the Environment has developed a list of guiding principles for determining the numerical soil quality remediation objectives for contaminated sites. Human health, environmental quality, and land use are considered [37]. Furthermore, the CCME encourages remediation of a contaminated site to the lowest level practicable in the context of its intended land use and technological limitations. Where application of these guidelines is not possible, a risk-informed approach is used. In this way, Canada accepts that MEC-contaminated sites cannot be fully remediated and instead focuses on reducing risk, even if that risk is only qualitative.

\section{Discussion}

While most countries consider current and potential land uses in their consideration of MEC management, no universal methodologies, standards, or procedures for 'clean' with regard to MEC-contaminated sites have been 
established to date. This is highly problematic in an increasingly global community and poses particular difficulty for the United States Department of Defense, for example, whose land use - although not land ownership extends into other countries. Moreover, there is no general agreement on whether a risk-informed approach would improve this methodological disconnect due to a palpable undercurrent of liability should a risk-informed approach fail. That said, the three case study countries in this study appear to accept the reality that MEC-contaminated sites can never be pristine again. While inherent difficulties with MEC alongside political and cultural differences ensure that dissimilarities will exist within each nation, certain steps can be taken to both learn from past international experiences and leverage a baseline of best practices that a state's regulatory and oversight authority may make use of. Consequently, the most logical conclusions here would be to

1. Establish or leverage an existing international forum that brings the stakeholders (government, military, civilian, civic, populace, international organizations, non-governmental organizations, etc.) together with the objective to develop international standards for 'clean'.

2. Develop and test various risk-informed standards and methods for obtaining 'clean' standards.

3. Determine whether a risk-informed approach to obtaining 'clean' is both acceptable and feasible or whether another approach better helps achieve the objectives underlying 'clean'.

4. Implement the chosen 'clean' standard and methods for attaining 'clean' through an international treaty.

In an international environment, these suggestions could offer states a path forward to improve their MEC handling capabilities. The current situation leaves local decision makers open to liability and the populace at risk due to conflict and confusion regarding the standards and their meaning with regard to land use. Having states with competing policies as well as multiple standards and methodologies applied to this complex problem unnecessarily increases the difficulty in defining and resolving the issue at hand.

\section{Conclusion}

Efforts are currently underway at the European Union level to enact soil protection legislation, and this effort may someday expand to include MEC issues. Thus, far international environmental legislation regarding soil issues seems to have focused on soil protection through European Union (EU) policies on water, waste, chemicals, industrial pollution prevention, nature protection, pesticides, and agriculture. Although MEC has yet to be explicitly included in this effort, MEC management and remediation standards will undoubtedly be affected by any legislation that is developed as a result.

For the United States in particular, it is important to understand, in context, the MEC similarities in their European and North American counterparts. While it is not possible to culturally and politically mirror the exact regulatory and oversight environment of other nations, lessons can be learned from the successes and failures of all nations via a comparative analysis of differing countries as with those mentioned here. Examples from the UK, Germany, and Canada demonstrate certain successful risk management strategies and tactics that the US might consider adopting as well as an outline of common areas of capacity and areas requiring improvement. Again, while the bottom line of the United States' MEC story is not entirely inconsistent with these other nations, that said, it is evident here that policymakers from these four countries would all benefit from a review of the examples studied here to understand the value-added in creating both national and international MEC management standards and a formal, quantitative risk calculation methodology to review these decisions and their complex tradeoffs.

\section{Competing interests}

The authors declare that they have no competing interests.

\section{Authors' contributions}

IL conceived of the study and organized collaboration of other coauthors. RD and $\mathrm{MH}$ are engaged in data collection and overall analysis. BT drafted the manuscript and analyzed available qualitative information. IL, BT, and RD all engaged in revision of the test. All authors read and approved the final manuscript.

\section{Acknowledgements}

The authors would like to thank Elizabeth Jones and Vic Wieszek for their helpful discussion and assistance in the paper's preparation. The US Department of Defense funded the research described here. This article has been reviewed in accordance with the agency's peer and administrative review policies and has been approved for publication by the chief of engineers. The research described in this article does not reflect official views of USACE or DOD and lends no official endorsement.

\section{Author details}

'US Army Engineer Research and Development Center, 696 Virginia Rd, Concord, MA 01742, USA. STRATCON, LLC, 499 Belmont Bay Dr., Woodbridge, VA 22191, USA.

Received: 4 July 2014 Accepted: 26 October 2014 Published online: 26 November 2014

References

1. United States Department of Defense: Defense Environmental Programs. 2008.

2. United States Department of Defense: Defense Environmental Programs Annual Report to Congress (Fiscal Year 2008). Washington D.C: Office of the Deputy Assistant Secretary of Defense (Environment); 2008.

3. Lima DR, et al: Impact of ammunition and military explosives on human health and the environment. Rev Environ Health 2011, 26(2):101-110.

4. Downey DC, Benson LA, Taffinder SA: Trends In Regulatory Acceptance Of Risk-Based Cleanup Goals And Natural Attenuation For Site Closure. Remediation Journal 1997, 8(1):71-86.

5. United States Environmental Protection Agency: Munitions and explosives of concern hazard assessment methodology; 2008. 
6. Bureau of Land Management Protection and Response Group: Military munitions and explosives of concern: a handbook for federal land managers, with emphasis on unexploded ordnance, BLM Handbook H-1703-2. Washington, DC: US Department of the Interior and the Fish and Wildlife Service; 2005.

7. Brett $H$, Aker J, Reid M: Risk management for unexploded ordinance (UXO). In The marine environment. Dalhousie Journal of Interdisciplinary Management 8.2; 2012

8. Bolton MB: Foreign aid and landmine clearance: governance, politics and security in Afghanistan, Bosnia and Sudan, Volume 7. IB Tauris; 2010.

9. Lewis J: Unexploded ordnance and the environment - a legacy of past practices. 2010

10. Lotufo G, Kuperman RG: Ecotoxicology of explosives and unexploded ordnance. CRC Press; 2007

11. MacDonald Gibson J, et al: Communicating quantitative information about unexploded ordnance risks to the public. Environ Sci Technol 2013, 47(9):4004-4013.

12. Briggs $C$, Weissbecker I: Salting the Earth: environmental health challenges in post-conflict reconstruction. Assessing and Restoring Natural Resources in Post-conflict Peacebuilding 2012, 5:111.

13. Hooper AE: Unexploded ordnance (UXO): the problem, Detection and Identification of Visually Obscured Targets. 1998:1.

14. Byrnes JS: Unexploded ordnance detection and mitigation. Springer; 2009.

15. Garcia SS, et al: Discarded military munitions case study: ordnance reef (HI-06), Hawaii. Mar Technol Soc J 2009, 43(4):85-99.

16. Abbotts J: National monument locations and remediation of World War II battle sites. Remediat J 2009, 19(4):121-134.

17. Interstate Technology and Regulatory Council: Property revitalization - lessons learned from BRAC and Brownfields, BRNFLD-2. Washington D.C: Interstate Technology and Regulatory Council; 2006a.

18. United States Environmental Protection Agency: Handbook on the management of munitions response actions: interim final, EPA 505-B-01-001. Washington, DC: Office of Solid Waste and Emergency Response; 2005.

19. United States Environmental Protection Agency: EPA munitions response guidelines, draft. Washington, DC: Office of Solid Waste and Emergency Response; 2008a.

20. US EPA: EPA munitions response guidelines. 2010.

21. United States Environmental Protection Agency: National Priorities List (NPL). 2013.

22. Mackenzie CM, Jordan CM, Dugan RE, Kolodny MA: Detecting UXO: putting it all into perspective. In SPIE's 1995 Symposium on OE/Aerospace Sensing and Dual Use Photonics. International Society for Optics and Photonics; 1995:94-99.

23. MacDonald JA, Small MJ, Morgan G: Quantifying the risks of unexploded ordnance at closed military bases. Environ Sci Technol 2009, 43(2):259-265.

24. United Kingdom Secretary of State: The Contaminated Land (England) Regulations 2006, 2006 No. 1380. London: UK Secretary of State; 2006.

25. Stone K, Murray A, Cooke S, Foran J, Gooderham L: Unexploded Ordnance (UXO) - a guide for the construction industry. London: Classic House; 2009.

26. United Kingdom Ministry of Defense: Duty holders guide - guidance on the assessment and management of land contamination (IN 0708). London: Defense Estates; 2008.

27. United Kingdom Ministry of Defense: Handbook of defense: land ranges safety, Joint Service Publication 403, Volume 5: Demolitions, Ordnance Disposal and Battle Simulation. London: Defense Council; 2006.

28. German Federal Environment Agency: 'Germany,' Investigation, Assessment, and Clean-up of Contaminated Military Sites. 2007

29. ReMiDo: Environmental impact of post-soviet military residential areas. 2008:84

30. Jenkins TF, et al: Identity and distribution of residues of energetic compounds at army live-fire training ranges. Chemosphere 2006 63(8):1280-1290

31. Canadian Department of National Defense Unexploded Explosive Ordnance and Legacy Sites Program: The DND Unexploded Explosive Ordnance and Legacy Sites Program. Ottowa, Ontario: Department of National Defense; 2009.

32. Defense Construction Canada (DCC): Challenges + Solutions: Defense Construction (1951) Limited Annual Report 2008-2009. Ottowa, Ontario: DCC; 2009.

33. Canadian Council of Ministers of the Environment (CCME): Guidance Document on the Management of Contaminated Sites in Canada, PN 1279. Winnipeg, Manitoba: CCME; 1997:4-5.
34. Canadian Council of Ministers of the Environment (CCME): Canadian soil quality guidelines for the protection of environmental and human health: guidance manual for developing site-specific soil quality remediation objectives for contaminated sites in Canada. Winnipeg, Manitoba: CCME National Contaminated Sites Remediation Program (NCSRP); 1996:1.

35. Gagnon J, Braid M: Risk mitigation of military munitions in a sensitive ecosystem environment, lecture. Vancouver: Federal Contaminated Sites National Workshop; 2008.

36. DND UXO and Legacy Sites Program: Legacy Sites Program. 2013.

37. Gagnon J, Braid M: Risk mitigation of military munitions. 2012.

doi:10.1186/s12302-014-0030-5

Cite this article as: Linkov et al:: Munitions and explosives of concern: international governance and applications for the United States.

Environmental Sciences Europe 2014 26:30.

\section{Submit your manuscript to a SpringerOpen ${ }^{\circ}$ journal and benefit from:}

- Convenient online submission

- Rigorous peer review

- Immediate publication on acceptance

- Open access: articles freely available online

- High visibility within the field

- Retaining the copyright to your article

Submit your next manuscript at $>$ springeropen.com 